\title{
アモルファス $\mathrm{WO}_{3}-\mathrm{TiO}_{2}$ 薄膜を用いたEC素子の寿命
}

\author{
松岡 秀樹*, 橋本 哲**, 影近 博 ${ }^{* *}$
}

\author{
Lifetime of Electrochromism of Amorphous $\mathrm{WO}_{3}-\mathrm{TiO}_{2}$ Thin Films
}

Hıdekı MATSUOKA*, Satoshı HASHIMOTO** and Hıroshı KAGECHIKA**

\begin{abstract}
The degradation of electrochromism in amorphous $\mathrm{WO}_{3}-\mathrm{T}_{1} \mathrm{O}_{2}$ films prepared by electron-beam deposition have been studied and the lifetime of the $\mathrm{WO}_{3}-\mathrm{TlO}_{2}$ films was found to be five times greater than that of the $\mathrm{WO}_{3}$ films. Xray diffraction revealed that the crystal structure of the $\mathrm{WO}_{3}-\mathrm{T}_{1} \mathrm{O}_{2}$ films was still amorphous after the coloring and bleaching cycles, while a crystalline peak was observed in the amorphous $\mathrm{WO}_{3}$ films SIMS analysis revealed that lithium accumulated in the $\mathrm{WO}_{3}$ films, but not in the $\mathrm{WO}_{3}-\mathrm{T}_{1} \mathrm{O}_{2}$ films. The X-ray diffraction and XPS analysis revealed that the as-deposited $\mathrm{WO}_{3}-\mathrm{T}_{1} \mathrm{O}_{2}$ films were of an amorphous network structure based on the $\mathrm{WO}_{3}$ which has slightly shorter bonds length and that the $\mathrm{WO}_{3}-\mathrm{T}_{1} \mathrm{O}_{2}$ films are stable against the crystallization by annealing.

From these results, the $\mathrm{WO}_{3}-\mathrm{T}_{1} \mathrm{O}_{2}$ films have a small number of defect bonds that act as trapping sites for lithium. We conclude that the prolonged lifetime of electrochromism in $\mathrm{WO}_{3}-\mathrm{T}_{1} \mathrm{O}_{2}$ films is the result of reduced accumulation of lithium in the films.
\end{abstract}

Key Words Amorphous Thin Film, $\mathrm{WO}_{3}-\mathrm{T}_{1} \mathrm{O}_{2}$, Electrochromism, Lifetime, X-ray Diffraction

\section{1. 緒言}

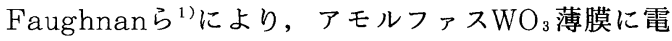
解質中における可逆的な電気化学反応に伴う色の変化 （エレクトロクロミズム）が見つけられて以来, EC（エ レクトロクロミック）表示材料や遮光材料などへ応用す る研究が行われている。アモルファス $\mathrm{WO}_{3}$ 薄膜のエレ クトロクロミズムの原理は, Faughnanらにより次式 のような二重注入モデルで説明されている ${ }^{1)}$ 。

$$
\mathrm{WO}_{3}+x \mathrm{~A}^{+}+x \mathrm{e}^{-} \rightleftarrows \underset{\text { (無色) }}{\mathrm{A}_{x} \mathrm{WO}_{3}}
$$

すなわち，陽イオン $\mathrm{A}^{+}(\mathrm{A}: \mathrm{H}$ ，Liなど）を含む電 解質中で, アモルファス $\mathrm{WO}_{3}$ 薄膜をカソードにして電 圧を印加すると, その中へ, 電解質から陽イオン $\mathrm{A}^{+}$が,

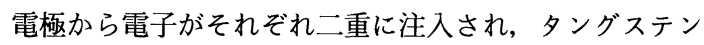
ブロンズ $\mathrm{A}_{x} \mathrm{WO}_{3}$ が生成し, 青色に発色する。一方, 逆 方向に電圧を印加すると, 逆向きの反応が生じ, 再び無 色に戻る。

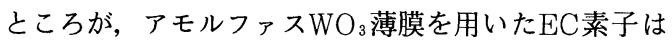
発色/消色を繰り返すことにより, 色が変化しなくなっ てしまい劣化することが知られている。Faughnanら

* NKK 鉄鋼研究所（示240 神奈川県川畸市川崎区南渡田町 1-1) [現 NKK 技術開発本部]

Steel Res Center, NKK Co (1-1, Minamıwatarıda-cho, Kawasakı-ku, Kawasakı-shı, Kanagawa 240)

〔Present Res and Dev Div, NKK Co ]

** NKK 鉄鋼研究所（广240 神奈川県川崎市川崎区南渡田町 1-1)

Steel Res Center, NKK Co (1-1, Minamıwatarida-cho, Kawasak1-ku, Kawasakı-shı, Kanagawa 240)
は電解質として硫酸を用いていたため, 繰り返し発色す るとアモルファス $\mathrm{WO}_{3}$ 薄膜が溶出し発色しなくなった。 そこで, $\mathrm{L}_{1} \mathrm{ClO}_{4}$ ープロピレンカーボネートなどの非水 溶媒電解質が用いられるようになった

しかし, 森田・鷲田は, 印加電圧 $2.5 \mathrm{~V}$, 繰り返し周 期 $1 \mathrm{~Hz}$ の条件で, $\mathrm{L}_{1} \mathrm{ClO}_{4}$ ープロピレンカーボネート電 解質を用いた $\mathrm{WO}_{3}$ 薄膜系 $\mathrm{EC}$ 素子の発色/消色の繰り返 し試験を行ったところ，106回で劣化することを報告し た ${ }^{3)}$ 。彼らは, $\mathrm{SIMS}$ 結果から $\mathrm{WO}_{3}$ 膜中への $\mathrm{L}_{1}$ の蓄積 が少化の原因であろうと報告した。Schlotter and P1ckelmann ${ }^{4}$ や吉池, 近藤 ${ }^{5}$ は, $\mathrm{WO}_{3}$ 膜中へのLiの蓄 積について, $\mathrm{WO}_{3}$ 膜中に蒸着中に導入されるW-O-H基 のHが, L1と置換し, W-O-Liという形で蓄積される, と提唱した。また, 筆者らは, 発色/消色を繰り返した とき, 消色時においてもWO 3 膜中にLiが存在すること, 多量に $\mathrm{L}_{1}$ を注入すると結晶質の $\mathrm{L}_{2} \mathrm{WO}_{4}$ が生成すること を明らかにした。そして, これらの結果から, 繰り返し 発色によってL1が多量に蓄積すると結晶質の $\mathrm{L}_{1} \mathrm{WO}_{4}$ が 生成し, Liの拡散が抑制されるために発色/消色を示さ なくなるすのと考えた ${ }^{6)}$ 。

このような劣化機構から，L1の蓄積が抑制できる薄 膜には寿命が長くなることが期待できる。そこで, WO-Hなど, L1が蓄積するサイトの少ない構造を実現さ せるため, $\mathrm{WO}_{3}$ より平衡酸素分圧の低いすなわち $\mathrm{WO}_{3}$ より安定な酸化物や, 結晶中にL1が拡散しやすいよう なトンネル構造を有するルチル型などの酸化物とWO の二元系酸化物薄膜を発色層として用い, その寿命につ いて調べた。そのうち, $\mathrm{WO}_{3}-\mathrm{T}_{1} \mathrm{O}_{2}$ 薄膜を用いたEC素 子ではWO $\mathrm{W}_{3}$ 薄膜のものより長い寿命が得られたので, 
Table 1 The experimental conditions of the deposition of the $\mathrm{WO}_{3}-\mathrm{MO}_{x}$ thin films.

\begin{tabular}{l|c|c}
\hline & Electron-beam deposition & K-cell deposition \\
\hline Pressure & $7 \times 10^{-6}$ Torr & $\begin{array}{c}5 \times 10^{-5} \mathrm{Torr} \\
\left(\text { after } \mathrm{O}_{2} \text { introduction }\right)\end{array}$ \\
\hline $\begin{array}{l}\text { Substrate } \\
\text { temperature }\end{array}$ & $187^{\circ} \mathrm{C}$ & $250^{\circ} \mathrm{C}$ \\
\hline Deposition rate & $10 \sim 50 \AA / \mathrm{s}$ & $05 \sim 5 \AA / \mathrm{s}$ \\
\hline
\end{tabular}

その長寿命化機構を薄膜の結晶構造, 電子構造に基づい て調べた結果を報告する。

\section{2. 実験方法}

\section{2. $1 \mathrm{WO}_{3}-\mathrm{MO}_{x}$ の成膜と用いたECセル}

電子ビーム蒸着法を用いて $\mathrm{WO}_{3}-\mathrm{MO}_{x}$ (金属酸化物) 二元系酸化物薄膜の成膜を行った。ここで, $\mathrm{MO}_{x}$ とし $\tau, \mathrm{Al}_{2} \mathrm{O}_{3}, \mathrm{SiO}_{2}, \mathrm{MgO}, \mathrm{Nb}_{2} \mathrm{O}_{5}, \mathrm{Ta}_{2} \mathrm{O}_{5}, \mathrm{ZrO}_{2}$, $\mathrm{NiO}, \mathrm{Cr}_{2} \mathrm{O}_{3}$ および $\mathrm{T}_{1} \mathrm{O}_{2}$ を用いた。なお， $\mathrm{WO}_{3}$ および $\mathrm{WO}_{3}-\mathrm{T}_{1} \mathrm{O}_{2}$ 薄膜の成膜にはクヌーセンセル蒸着法も用い た。いずれの蒸着法を用いても同様な皮膜が得られた。 基本的な成膜条件を表 1 に示す。それらの膜厚は，500 $\mathrm{nm}$ を標準とした。基板として，松崎真空㑣製のITOガ

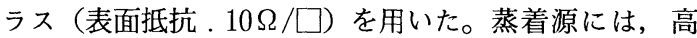
純度化学侏製の $\mathrm{WO}_{3}, \mathrm{Al}_{2} \mathrm{O}_{3}, \mathrm{~S}_{2} \mathrm{O}_{2}, \mathrm{MgO}, \mathrm{Nb}_{2} \mathrm{O}_{5}$, $\mathrm{Ta}_{2} \mathrm{O}_{5}, \mathrm{ZrO}_{2}, \mathrm{NiO}, \mathrm{Cr}_{2} \mathrm{O}_{3}$ および $\mathrm{TiO}_{2}$ を用いた。 $\mathrm{WO}_{3}-\mathrm{MO}_{x}$ 薄膜を成膜するには, 二つの蒸発源から同時 に $\mathrm{WO}_{3}$ と $\mathrm{MO}_{x}$ とを蒸発させる共蒸着法を用いた。それ ぞれの蒸着速度を調節することにより, 組成の制御を行っ た。

成膜したWO $\mathrm{WO}_{3}-\mathrm{MO}_{x}$ 薄膜を作用極, $\mathrm{Pt}$ あいはITOガ ラスを対極として，ECセルを作製した。電解質として， $1 \mathrm{M} \mathrm{L} \mathrm{ClO}_{4}$ ープロピレンカーボネート溶液を用いた。

\section{2 発色/消色の繰り返し試験}

$\mathrm{WO}_{3}-\mathrm{MO}_{x}$ 薄膜とITOガラスとの間に，定電圧の条件 で2.5V印加し180s間の発色/消色を行った。発色/消色 時の電荷量および発色/消色前後での吸収スペクトルを 分光光度計（㑣日立製作所 330型）で測定した。

また, $\mathrm{WO}_{3}-\mathrm{MO}_{x}$ 薄膜とPt線之の間に定電圧の条件で 電圧を印加し, 以下に示すサイクルで, 繰り返し試験を 行った。

(発色) $2.5 \mathrm{~V} \times 180 \mathrm{~s} \rightarrow$ (停止) $0 \mathrm{~V} \times 20 \mathrm{~s}$

$\rightarrow$ (消色) $2.5 \mathrm{~V} \times 180 \mathrm{~s} \rightarrow$ (次の発色)

その際，透過率（波長850nm）の变化も同時に測定 した。

\section{3 薄膜の構造解析}

$\mathrm{WO}_{3}-\mathrm{T}_{1} \mathrm{O}_{2}$ 薄膜に対して, 以下のような薄膜の構造解 析を行った。SEM-EDXS（走查型電子顕微鏡一エネル ギー分散型X線分析装置，JEOL T-330，JED2000） を用いて, $\mathrm{WO}_{3}-\mathrm{T}_{1} \mathrm{O}_{2}$ 薄膜の組成の決定を行った。また,

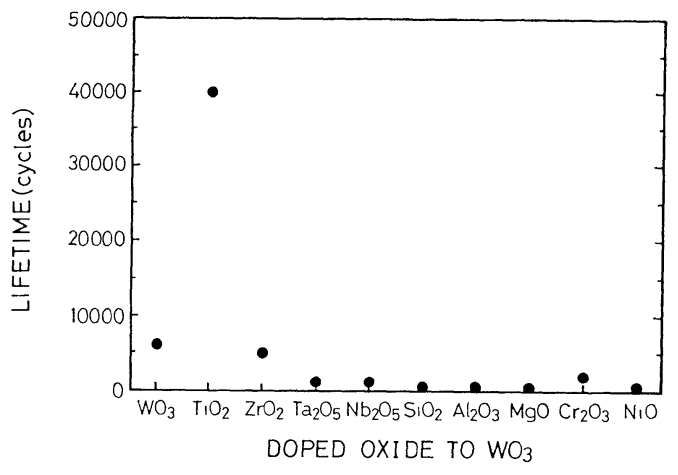

Fig. 1 The lifetime of the electrochromism for the various $\mathrm{WO}_{3}-\mathrm{MO}_{x}$ thin films

ICP（誘導結合プラズマ発光分光法，日立P5200）を用 いて，EDXSによる定量分析値を較正した。

薄膜試料測定用のアタッチメントを用いたX線回折法 （リガクRAD-RC）で, $\mathrm{WO}_{3}-\mathrm{T}_{1} \mathrm{O}_{2}$ 薄膜の結晶構造解 析を行った。X線源としてCuK $\alpha$ を用いた。また， SIMS (2 次イオン質量分析法, Cameca IMS- 3 F) により, $\mathrm{WO}_{3}-\mathrm{T}_{1} \mathrm{O}_{2}$ 薄膜中に存在する元素の深さ方向分 析を行った。1 次イオンとして，Ar+用いた。さらに， XPS（X線光電子分光法, SSI SSX-100）を用いて, Ti 2 P，W 4 f光電子ピークを測定した。X線源として 単色化した $\mathrm{AlK} \alpha$ を用いた。試料表面の還元を防ぐため, $\mathrm{Ar}^{+}$イオンスパッタリングは行わなかった。

\section{3. 結果および考察}

$\mathrm{WO}_{3}-\mathrm{MO}_{x} 2$ 元系酸化物系薄膜のエレクトロクロミッ クな発色/消色の寿命を図 1 に示す。ここで，安定した

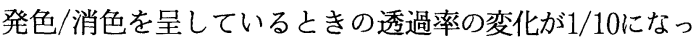
たときを寿命と定義した。 $\mathrm{WO}_{3}$ 薄膜の寿命に比べると， $\mathrm{WO}_{3}-\mathrm{T}_{1} \mathrm{O}_{2}$ 薄膜を用いた場合のみ寿命が向上した。

図 2 に，様々な濃度を有する $\mathrm{WO}_{3}-\mathrm{T}_{1} \mathrm{O}_{2}$ 薄膜の発色効 率を示す。発色効率 $(\eta)$ は，(2)式で定義した。

$$
\eta=O D / q
$$

ここで, $O D は$ 発色した薄膜の成膜ままのものに対す る単位膜厚当たりの光学密度の変化 (波長 $800 \mathrm{~nm}$ ) で あり, $q$ は 2 回目発色時の単位体積当たりの注入電荷量 である。 $\mathrm{T}_{1} \mathrm{O}_{2}$ 濃度に比例して, 発色効率はわずかに減 少する。 $\mathrm{T}_{1} \mathrm{O}_{2}$ の濃度が $10 \mathrm{~mol} \%$ の $\mathrm{WO}_{3}-\mathrm{T}_{1} \mathrm{O}_{2}$ 薄膜の発 色効率は $\mathrm{WO}_{3}$ の $90 \%$ 程度であった。この濃度範井にお いて, $\mathrm{WO}_{3}-\mathrm{TiO}_{2}$ 薄膜の発色効率は, $\mathrm{WO}_{3}$ 薄膜のもの とほぼ同程度であるといえる。また，発色した $\mathrm{WO}_{3}$ $\mathrm{T}_{1} \mathrm{O}_{2}$ 薄膜の吸収スペクトル，あるいはXPSを用いて測 定した発色前後の価電子帯の変化は $\mathrm{WO}_{3}-\mathrm{TiO}_{2}$ 薄膜之同 様であったため ${ }^{7)}, \mathrm{WO}_{3}-\mathrm{TiO}_{2}$ 薄膜の発色機構はWO 3 膜の場合 ${ }^{8)}$ 之同じであると考えられる。 


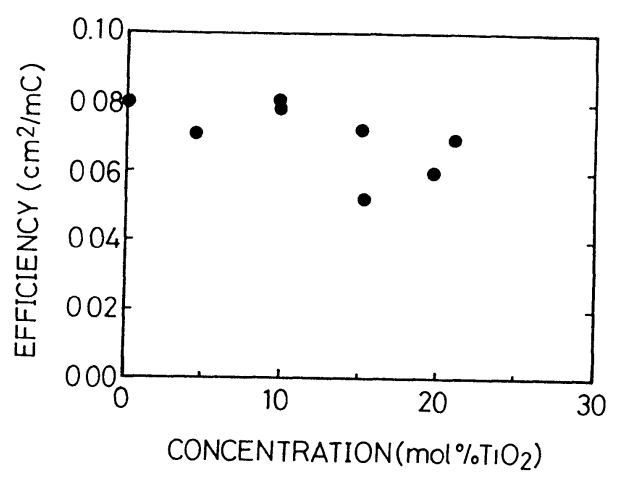

Fig. 2 The efficiency of the coloration of the $\mathrm{WO}_{3}-\mathrm{T}_{1} \mathrm{O}_{2}$ thin films as a function of the concentration of $\mathrm{T}_{1} \mathrm{O}_{2}$.
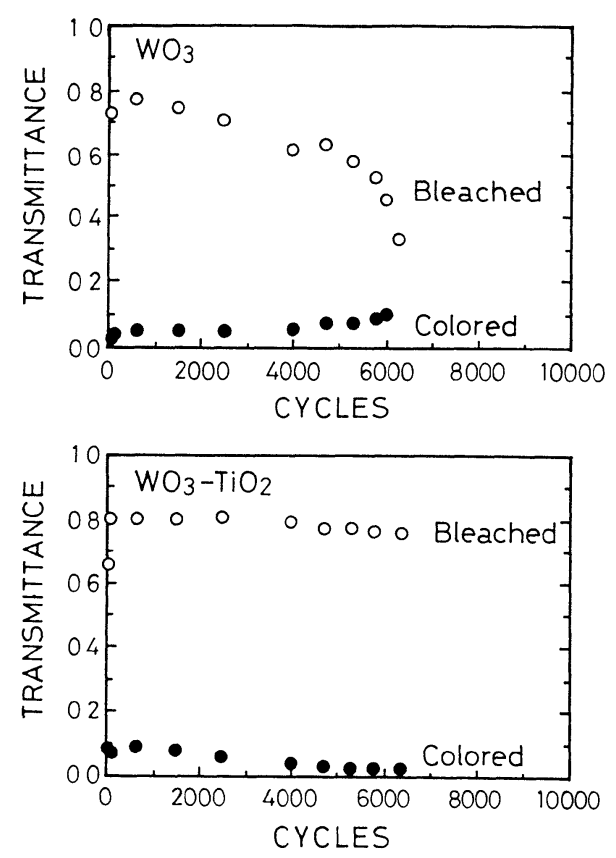

Fig. 3 The transmittance of the $\mathrm{WO}_{3}$ and $\mathrm{WO}_{3}-\mathrm{T}_{1} \mathrm{O}_{2}$ films as a function of the coloring and bleaching cycles

図 3 に, 繰り返し発色/消色したEC素子の透過率の変 化を示す。 $\mathrm{WO}_{3}$ 薄膜を用いたEC素子の場合には， 6500 回で劣化したのに対し, $\mathrm{WO}_{3}-\mathrm{TiO}_{2}\left(15.9 \mathrm{~mol} \% \mathrm{TiO}_{2}\right)$ 薄膜を用いたEC素子では，同じ繰り返し回数でも，劣 化していない。図4 亿，濃度に対する $\mathrm{WO}_{3}-\mathrm{T}_{1} \mathrm{O}_{2}$ 系 $\mathrm{EC}$ 素子の寿命を示す。 $\mathrm{TiO}_{2}$ を添加すると, $\mathrm{WO}_{3}$ に比べ寿 命が長くなることが明らかである。特に, $\mathrm{TiO}_{2}$ 濃度が, 約 $10 \mathrm{~mol} \%$ の場合, $\mathrm{WO}_{3}$ に比べ 5 倍以上の寿命となり, もっとも長寿命化した。 $\mathrm{TiO}_{2}$ 濃度が $15 \mathrm{~mol} \%$ より高 くなると，寿命は最大値よりも短くなった。しかし， $\mathrm{T}_{1} \mathrm{O}_{2}$ 濃度が $20 \mathrm{~mol} \%$ の時であ, 寿命は $\mathrm{WO}_{3}$ に比べて 2 倍程度高い。そこで, $\mathrm{WO}_{3}-\mathrm{T}_{1} \mathrm{O}_{2}$ 薄膜を用いた時, なぜ 長寿命化するのかを，X線回折，SIMSなどを用いて調

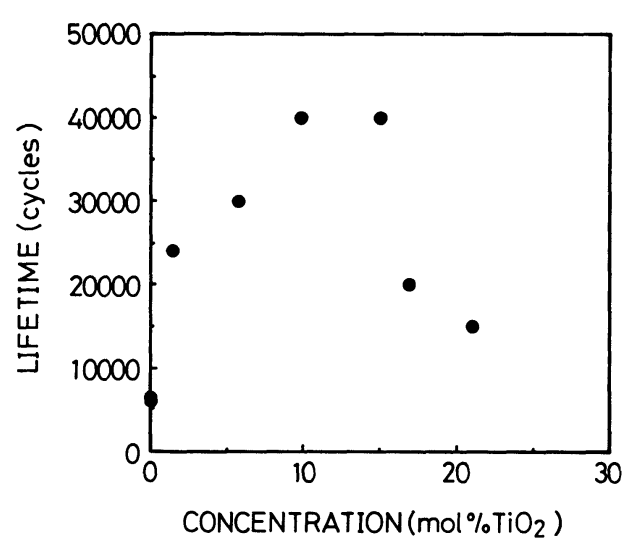

Fig. 4 The lifetime of the $\mathrm{WO}_{3}-\mathrm{T}_{1} \mathrm{O}_{2}$ films as a function of the concentration of $\mathrm{T}_{1} \mathrm{O}_{2}$

べた。

図 5 に, 繰り返し試験を行ったときの, $\mathrm{WO}_{3}$ 薄膜お よび $\mathrm{WO}_{3}-\mathrm{TiO}_{2}$ 薄膜のX線回折図形の変化を示す。いず れの場合す, 3000回の絽り返しでは, 膜はアモルファス のままであるが, $\mathrm{WO}_{3}$ 薄膜の場合, 4500回の繰り返し で, $\mathrm{In}_{2} \mathrm{O}_{3}$ 以外の結晶性ピークが出現し, 完全に劣化し た6500回では，これらのピークがさらに大きくなった。 これらは, Li-W-O三元系化合物であるものと考えられ $3^{6)}$ 。 $\mathrm{WO}_{3}-\mathrm{T}_{1} \mathrm{O}_{2}$ 薄膜の場合は, 6500回の繰り返しです このような結晶性のピークは見られず，アモルファスの ままであった。このことは, 長寿命化した $\mathrm{WO}_{3}-\mathrm{T}_{1} \mathrm{O}_{2}$ 薄 膜では $\mathrm{WO}_{3}$ 薄膜に比べ, 発色の繰り返し数が多くなっ ても，アモルファスの構造を保っていることを示してい る。筆者らは, アモルファス $\mathrm{WO}_{3}$ 系エレクトロクロミッ ク素子が劣化するのは, 繰り返し発色/消色中に生じる $\mathrm{Li}$ の蓄積により結晶性の $\mathrm{Li}_{2} \mathrm{WO}_{4}$ が生成するためである と報告した ${ }^{6)}$ 。今回の結果はこの考え方と一致するあの である。

成膜ままの $\mathrm{WO}_{3}$ および $\mathrm{WO}_{3}-\mathrm{TiO}_{2}$ 薄膜, 発色したす の，消色したもの，および電解液中に 27 時間浸せきした あのについて, SIMSを用い薄膜中で測定されたL1 2 次 イオンの積分強度を図 6 に示す。 $\mathrm{WO}_{3}, \mathrm{WO}_{3}-\mathrm{T}_{1} \mathrm{O}_{2}$ 薄 膜いずれも，消色時に発色時の $1 / 2$ から $1 / 3$ の量のL 1 が 膜中に存在している。さらにその量はそれぞれの膜を電 解液に浸せきしたあのの場合とほぼ同程度である。しか し，消色あるいは浸せきした $\mathrm{WO}_{3}-\mathrm{TiO}_{2}$ 薄膜中に存在す るLiの量は, $\mathrm{WO}_{3}$ 薄膜の場合よりあ少ないことが明ら かである。このことは, 繰り返し発色させた時, $\mathrm{WO}_{3}$ $\mathrm{TiO}_{2}$ 薄膜ではWO 3 薄膜の場合と比べ, 発色に寄与しな いL1の蓄積が抑制されることを示している。 $\mathrm{WO}_{3}-\mathrm{TiO}_{2}$ 薄膜では, $\mathrm{L} 1$ の蓄積が抑制される結晶構造となってい ることが考えられるので, X線回折を用い，その結晶構 造の解析を行った。 

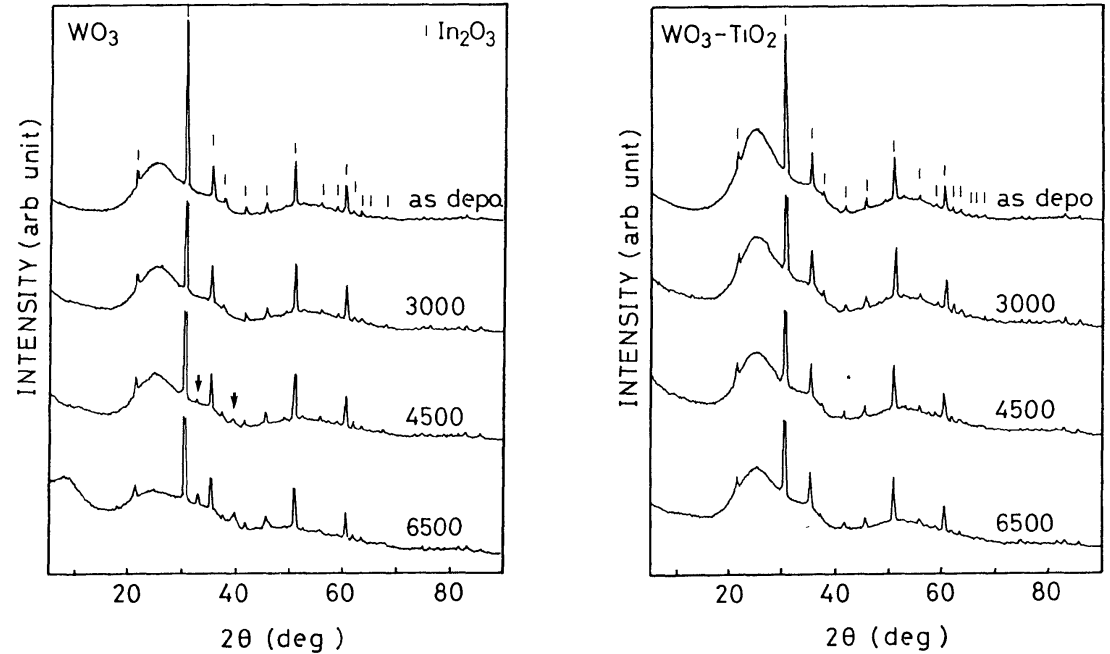

Fig. 5 X-ray diffraction patterns of the $\mathrm{WO}_{3}$ and $\mathrm{WO}_{3}-\mathrm{T}_{1} \mathrm{O}_{2}\left(15.6 \mathrm{~T}_{1} \mathrm{O}_{2} \mathrm{~mol} \%\right)$ thin films after the coloring and bleaching cycles

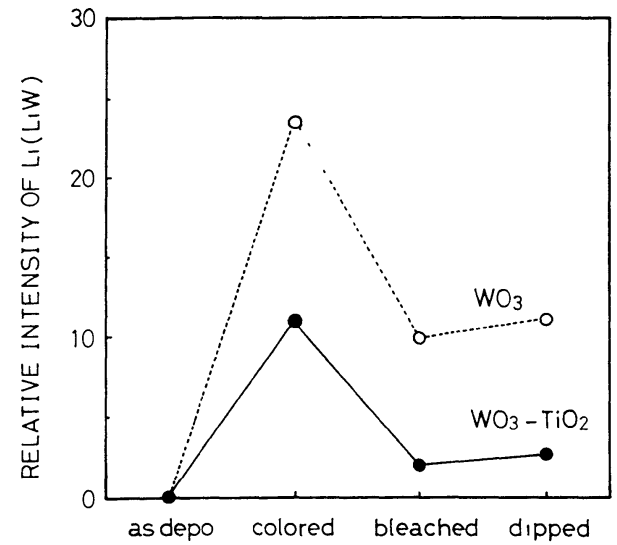

Fig. 6 The diagram of the integrated seconday ion intensity of lithium obtained in the as-deposited $\mathrm{WO}_{3}$ film, the colored film, the bleached film and the dipped film in the $\mathrm{L}_{1} \mathrm{ClO}_{4} \mathrm{PC}$ electrolyte for 27 hours and those of $\mathrm{WO}_{3}-\mathrm{T}_{1} \mathrm{O}_{2}\left(156 \mathrm{TlO}_{2} \mathrm{~mol} \%\right)$ films

図7に，様々な $\mathrm{TiO}_{2}$ 組成における，成膜ままの $\mathrm{WO}_{3}-$ $\mathrm{T}_{1} \mathrm{O}_{2}$ 薄膜のX線回折図形を示す。それぞれのX線回折 図形について, $2 \theta=25^{\circ}, 52^{\circ}$ に極大を持つハローが見 られることから, 成膜ままの $\mathrm{WO}_{3}-\mathrm{TiO}_{2}$ 薄膜はアモルファ スであることがわかる。結晶性の鋭いピークは $\operatorname{In}_{2} \mathrm{O}_{3}$ の あのと同定されたので，基板として用いたITOガラスに 起因するあのである。

これらのハローには, それぞれ $2 \theta=25^{\circ}, 35^{\circ}, 52^{\circ}$ に極大を持つ 3 つのピーク $\mathrm{A}, \mathrm{B}, \mathrm{Cが}$ 見られる。強度 が最す高いピーク $\mathrm{A} の$ 角度の $\mathrm{T}_{1} \mathrm{O}_{2}$ 濃度に対する変化を 図 8 に示す。若干のバラッキはあるあのの, $\mathrm{T}_{1} \mathrm{O}_{2}$ が多 くなるにつれ, Aのピーク位置は高角度側にシフトして

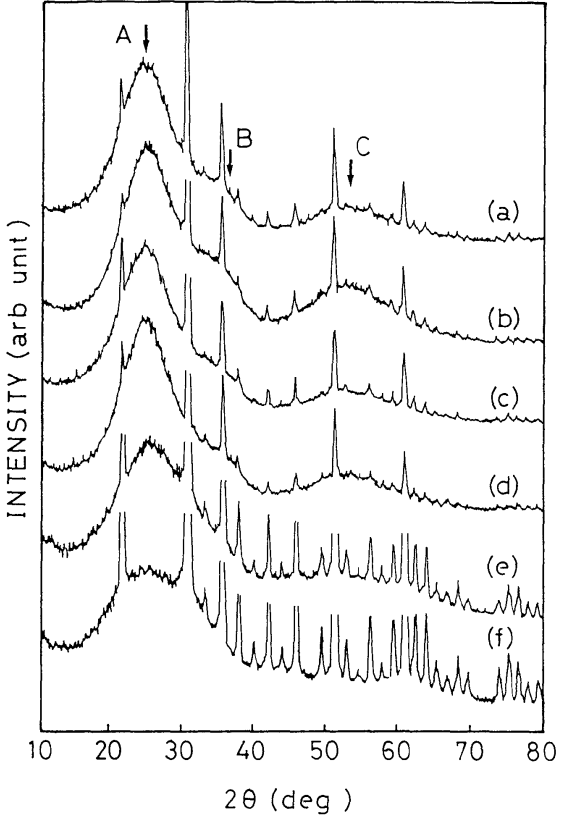

Fig. $7 \mathrm{X}$-ray diffraction patterns of the as-deposited $\mathrm{WO}_{3}$ $\mathrm{T}_{10}$ thin films ; (a) $\mathrm{WO}_{3}$, (b) $66 \mathrm{~mol} \% \mathrm{~T}_{1} \mathrm{O}_{2}$, (c) 98 $\mathrm{mol} \% \mathrm{~T}_{1} \mathrm{O}_{2}$, (d) $156 \mathrm{~mol}_{0} \mathrm{TiO}_{2}$, (e) $65.6 \mathrm{~mol} \% \mathrm{~T}_{1} \mathrm{O}_{2}$ and (f) $\mathrm{T}_{1} \mathrm{O}_{2}$.

いる。また, $65.6 \mathrm{~mol}_{0} \mathrm{TiO}_{2}$, および $100 \mathrm{~mol} \% \mathrm{~T}_{1} \mathrm{O}_{2}$ の $\mathrm{WO}_{3}-\mathrm{T}_{1} \mathrm{O}_{2}$ 薄膜では, ピーク $\mathrm{B}, \mathrm{C}$ がいずれも見られ ない。本来, アモルファスのハローパターンは動径分布 関数のフーリエ変換に対応し, 最近接の原子間距離に対 応した主成分が現れるほか，希薄物質近似が適応できな い通常の固体ではクラスター間の相関に対応した副次成 分も現れる ${ }^{9)}$ 。したがって, $\mathrm{WO}_{3}-\mathrm{TiO}_{2}$ 薄膜に見られた 


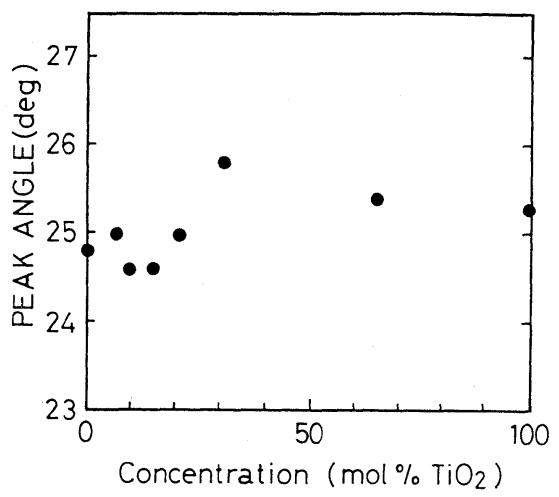

Fig. 8 The Bragg angle of peak A (indicated in Fig. 7) as a function of the concentration of $\mathrm{TiO}_{2}$.

ピーク Aの高角側へのシフトは, 原子間距離が小さくなっ たことに対応するものと言える。すなわち， $\mathrm{TiO}_{2}$ を添 加すると, アモルファス $\mathrm{WO}_{3}$ 中のW-O結合距離が短く なるあのと考えることができる。このことは，EELSや ラマン分光法の結果からあ確認された ${ }^{7)}$ 。また, $\mathrm{TiO}_{2}$ 組成の高いアモルファス $\mathrm{WO}_{3}-\mathrm{TiO}_{2}$ 薄膜でピーク Bが見 られないことは, $\mathrm{WO}_{6} 8$ 面体のクラスター間の相関距 離が変化したことによるあのと考えられる。代表的な結 晶性 $\mathrm{WO}_{3}$ は $\mathrm{WO}_{6} 8$ 面体の頂点を共有する $\mathrm{ReO}_{3}$ 型構造 をとり, $\mathrm{TiO}_{2}$ では $\mathrm{TiO}_{6} 8$ 面体の辺を共有するルチル構 造をとる ${ }^{10}$ 。また, アモルファ ス $\mathrm{WO}_{3}$ 薄膜では $\mathrm{WO}_{6}$
8 面体のクラスターを基本として薄膜成長するとされて いる ${ }^{11}$ 。したがって, $\mathrm{TiO}_{2}$ の組成が低いアモルファス $\mathrm{WO}_{3}-\mathrm{TiO}_{2}$ 薄膜は $\mathrm{WO}_{6} 8$ 面体の頂点を共有する $\mathrm{WO}_{3}$ と 同様なネットワーク構造をとっているが, $\mathrm{TiO}_{2}$ の組成 が高くなると $\mathrm{TiO}_{6} 8$ 面体が $\mathrm{WO}_{6} 8$ 面体を置換し, W-O の結合距離が短くなったネットワーク構造に変化したも のと考えられる。

成膜ままの $\mathrm{WO}_{3}-\mathrm{TiO}_{2}$ 薄膜について $\mathrm{Ti} 2 \mathrm{p}$ および W $4 \mathrm{f} X P S$ スペクトルを測定したところ, Ti $2 \mathrm{p}_{3 / 2}$ のピー

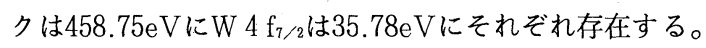
得られたTi $2 \mathrm{p}_{3} / 2$ 結合エネルギーは, Wagnerらによる ルチル構造の $\mathrm{TiO}_{2}$ のもの ${ }^{12)}$ と一致するので, $\mathrm{WO}_{3}$ $\mathrm{TiO}_{2}$ 薄膜中でTiは, +4 価で存在している。また, $\mathrm{W} 4 \mathrm{f}_{7 / 4}$ の結合エネルギーは, Coltonらによるもの ${ }^{13)}$ と 一致し +6 価で存在していることがわかる。このことは, アモルファス $\mathrm{WO}_{3}-\mathrm{TiO}_{2}$ 薄膜中で, 結晶性の $\mathrm{WO}_{3}$,

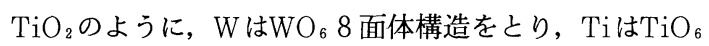
8 面体構造をとっていることを示唆している。

以上で示したXPSおよびX線回折の結果から，アモ ルファス $\mathrm{WO}_{3}-\mathrm{TiO}_{2}$ 薄膜は, アモルファス $ス \mathrm{WO}_{3}$ 薄膜と ほぼ同様, $\mathrm{WO}_{6} 8$ 面体を基本とするネットワークを有 し, その原子間距離が若干短くなった構造であるあのと 思われる。

成膜ままのあのに見られたネットワーク構造の変化が 結晶化を抑制するのかを調べるため, アモルファス $\mathrm{WO}_{3}-\mathrm{TiO}_{2}$ 薄膜を熱処理し, 結晶構造の変化を調べた。

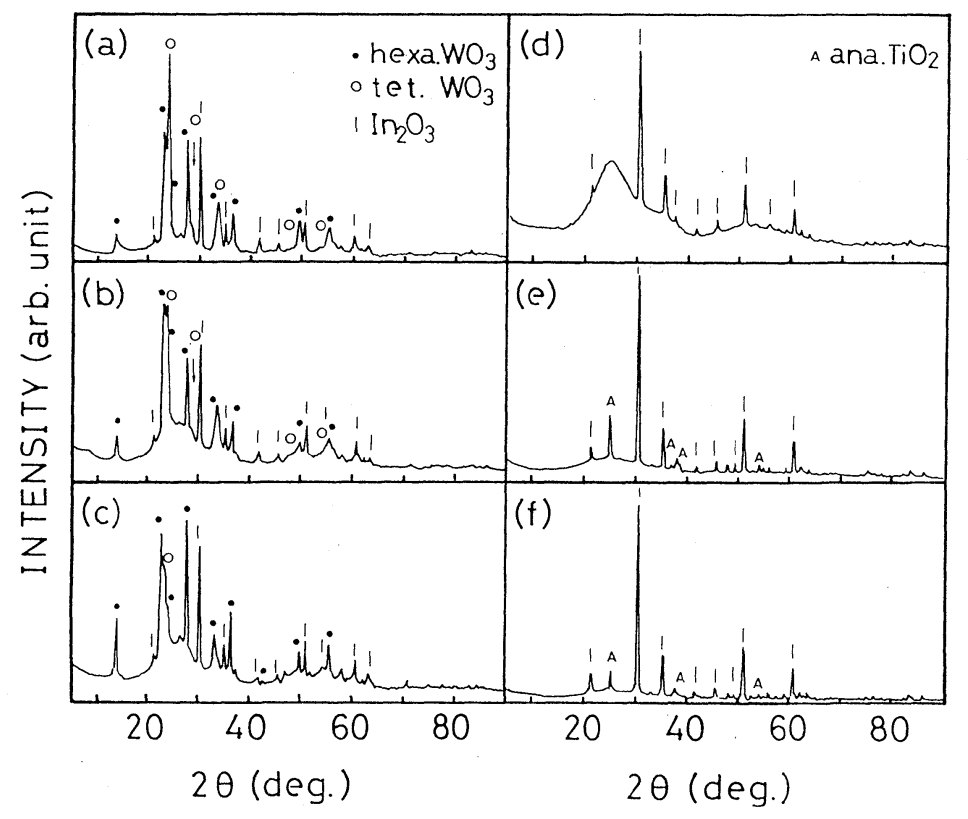

Fig. $9 \mathrm{X}$-ray diffraction patterns of the anealled $\mathrm{WO}_{3}-\mathrm{TiO}_{2}$ thin films at $400^{\circ} \mathrm{C}$ for 1 hour in the air. (a) $\mathrm{WO}_{3}$, (b) $6.6 \mathrm{~mol} \% \mathrm{TiO}_{2}$, (c) $9.8 \mathrm{~mol}_{0} \mathrm{TiO}_{2}$, (d) $21.0 \mathrm{~mol}_{0} \mathrm{TiO}_{2}$, (e) $65.6 \mathrm{~mol} \% \mathrm{TiO}_{2}$ and (f) $\mathrm{TiO}_{2}$. 
図 9 に，50mCを注入して発色させた後，大気中で 400 ${ }^{\circ} \mathrm{C} \times 1 \mathrm{~h}$ の条件で熱処理した $\mathrm{WO}_{3}-\mathrm{TiO}_{2}$ 薄膜のX線回折 図形を示す。熱処理したWO 起因するハローはほとんどみられず, 鋭いピークがみら れる。これらのピークは, 正方晶および六方晶の $\mathrm{WO}_{3}$ によるものと同定された。 $\mathrm{TiO}_{2}$ 濃度が $6.6 \mathrm{~mol} \%$ ， $9.7 \mathrm{~mol} \%$ の場合には, 正方晶のWO $\mathrm{WO}_{3}$ の成分とともにアモルファス $\mathrm{WO}_{3}$ に起因するハロー が明らかに存在する。 $\mathrm{TiO}_{2}$ 濃度が増えるとともに, 正 方晶の $\mathrm{WO}_{3}$ の量が減少し六方晶のものの量が増加して いる。さらに, $\mathrm{TiO}_{2}$ 濃度が $65.6 \mathrm{~mol} \%$ あのおよび $\mathrm{TiO}_{2}$ 薄膜の場合, ハローはほとんどみられず, 結晶性 ピークのみが存在する。これらは, アナターゼ型の $\mathrm{TiO}_{2}$ と同定された。これらでは, 結晶性 $\mathrm{WO}_{3}$ のピークはみ られなかった。 $\mathrm{WO}_{3}-\mathrm{TiO}_{2}$ 薄膜の熱処理後の構造は, $\mathrm{TiO}_{2}$ 濃度が低いときにはWO 3 を基本とするネットワー ク構造をとり, $\mathrm{TiO}_{2}$ 濃度が高くなると $\mathrm{TiO}_{2}$ を基本とす るものになる。 $\mathrm{TiO}_{2}$ の濃度によって薄膜の構造が変化 することは, 成膜ままの $\mathrm{WO}_{3}-\mathrm{TiO}_{2}$ 薄膜から得られた $\mathrm{X}$ 線回折の結果と一致している。

以上の結果より，もっとあ長寿命化した $\mathrm{TiO}_{2} 10 \mathrm{~mol}$ $\%$ 程度の濃度範囲において, $\mathrm{WO}_{3}-\mathrm{TiO}_{2}$ 薄膜は $\mathrm{WO}_{3}$ 薄 膜に比べ，熱処理を行っても，アモルファスの成分が残 存しやすいことが明らかである。 $\mathrm{TiO}_{2}$ を添加すること はアモルファス $\mathrm{WO}_{3}$ 薄膜を結晶化しにくくし，アモル ファス構造を安定化させる効果があるものと考えられる。 一方，アモルファス $\mathrm{WO}_{3}$ 薄膜のエレクトロクロミズム の劣化は, Liの蓄積による薄膜の結晶化に起因すると 考えられている ${ }^{6)}$ 。加熱に対しアモルファス構造を安定 化させたように, $\mathrm{TiO}_{2}$ を添加すると， Liの蓄積によっ て生じるアモルファス $\mathrm{WO}_{3}$ 薄膜の結晶化む抑制される あのと考えられる。

吉池, 近藤は, アモルファス $\mathrm{WO}_{3}$ 薄膜中に導入され たO-HにLiが蓄積されることを示し ${ }^{5)}$ ， ラマン分光の結 果から, $\mathrm{W}=\mathrm{O}$ の結合も膜中に存在することも知られて いる ${ }^{14)}$ 。SIMSの結果に見られたように, $\mathrm{WO}_{3}-\mathrm{TiO}_{2}$ 薄 膜ではLiの蓄積が抑制されているので, $\mathrm{WO}_{3}-\mathrm{TiO}_{2}$ 薄 膜はW-O-HやW=OなどLiを蓄積するサイトが少ない 構造であるものと考えられる。また，X線回折，XPS の結果から，その構造はWO 3 を基本とするすのの, $\mathrm{WO}_{3}$ 薄膜に比べW-Oの結合距離が短くなっている。また, $\mathrm{WO}_{3}-\mathrm{TiO}_{2}$ 薄膜では, $\mathrm{WO}_{3}$ に比べて結晶化しにくい。

これらの結果から考えられる $\mathrm{WO}_{3}-\mathrm{TiO}_{2}$ 薄膜のネット ワーク構造を図10に示す。 $\mathrm{TiO}_{2}$ 無添加のWO 3 では，吉 池，近藤の指摘するようなW-O-Hや，W=Oが存在し ているものと考えられる。 $\mathrm{WO}_{3}-\mathrm{TiO}_{2}$ 薄膜の場合, $\mathrm{Ti}$ が酸化力の大きな元素であるため, W-O-H, W=Oな ごの結合に, $\mathrm{TiO}_{2}$ が入りW-O-Ti-O-Wとなる，あるい

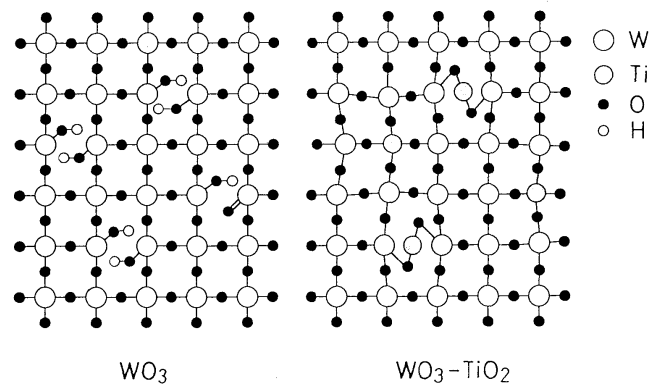

Fig. 10 The model for the network of amorphous (a) $\mathrm{WO}_{3}$ and (b) $\mathrm{WO}_{3}-\mathrm{TiO}_{2}$ thin films.

はWO 68 面体を $\mathrm{TiO}_{6} 8$ 面体が置換したものと考えられ る。さらに, $\mathrm{TiO}_{2}$ が置換した周囲の結合距離は若干短 くなっている。したがって, アモルファス $\mathrm{WO}_{3}-\mathrm{TiO}_{2}$ 薄 膜は以上で示したような「ネットワーク強化モデル」構 造をとっているため繰り返し発色させた時, Liの蓄積 が抑制される。そのため, Liの蓄積による結晶化に対 し，アモルファス $\mathrm{WO}_{3}$ を基本とするネットワーク構造 が安定に保たれる。その結果, $\mathrm{WO}_{3}-\mathrm{TiO}_{2}$ 薄膜では $\mathrm{WO}_{3}$ 薄膜に比べて長寿命化したものと考えられる。

最後に, 図4 に見られるように, $\mathrm{TiO}_{2}$ 濃度が $15 \mathrm{~mol}$ \%より高くなると, 最大を示したときに比べ $\mathrm{WO}_{3}-\mathrm{TiO}_{2}$ 薄膜の寿命は短くなる。図 2 に見られるようにこの濃度 領域では発色効率も低下するので，発色に寄与しない Liが多量に薄膜中に注入されているものと思われる。 そのため, $\mathrm{TiO}_{2}$ 濃度が $15 \mathrm{~mol} \%$ よも高い領域では, $\mathrm{WO}_{3}-\mathrm{TiO}_{2}$ 薄膜においてもLiの蓄積が促進されるよう になり，劣化しやすくなったあのと考えられる。

\section{4. 結 論}

真空蒸着法を用いて, アモルファス $\mathrm{WO}_{3}-\mathrm{MO}_{x}$ 二元系 酸化薄膜を作製し，そのエレクトロクロミックな繰り返 し発色特性を調べた。それらのうち， $\mathrm{WO}_{3}-\mathrm{TiO}_{2}$ 薄膜を 用いたEC素子では, $\mathrm{WO}_{3}$ 薄膜の場合に比べ 5 倍以上の 寿命を有することが明らかとなった。そこで，X線回折， SIMS，XPSを用いて, $\mathrm{WO}_{3}-\mathrm{TiO}_{2}$ 薄膜の結晶構造, 電 子構造を調べることにより，この薄膜がこのような長い 寿命をあつ理由を明らかとした。

X線回折の結果, 繰り返し発色させたアモルファス $\mathrm{WO}_{3}$ 薄膜には結晶性のピークが見られるのに対し，同 じ回数発色させた $\mathrm{WO}_{3}-\mathrm{TiO}_{2}$ 薄膜ではアモルファスのま まであった。SIMSの結果から，発色/消色の繰り返し 後, 消色した薄膜に蓄積されるLiの量は $\mathrm{WO}_{3}-\mathrm{TiO}_{2}$ 薄 膜の方がWO $\mathrm{W}_{3}$ 薄膜に比べ少ないことが明らかとなった。 濃度の異なる成膜ままの $\mathrm{WO}_{3}-\mathrm{TiO}_{2}$ 薄膜のX線回折の結 果から, $\mathrm{TiO}_{2}$ 濃度の低い領域で $\mathrm{WO}_{3}-\mathrm{TiO}_{2}$ 薄膜は, 結 合距離がわずかに短い $\mathrm{WO}_{3}$ を基本とするアモルファス 
のネットワーク構造をとっていることがわかった。さら に, 濃度の高い領域では構造が変化し $\mathrm{TiO}_{2}$ を基本とす るネットワーク構造になっている。XPSの結果から, $\mathrm{WO}_{3}-\mathrm{T}_{1} \mathrm{O}_{2}$ 薄膜に存在する $\mathrm{Ti}$ は $\mathrm{TiO}_{2}$ として存在してい る。また, 発色後加熱した $\mathrm{WO}_{3}-\mathrm{TiO}_{2}$ 薄膜は $\mathrm{WO}_{3}$ 薄膜 に比べ,アモルファスが残存しやすいことあ明らかとなっ た。

以上の結果から, $\mathrm{WO}_{3}-\mathrm{T}_{1} \mathrm{O}_{2}$ 薄膜は, $\mathrm{Li}$ の蓄積サイ トとなるW-O-HやW = O どの結合が少なくなり, W と○とでできたネットワーク構造が強化された構造をとっ ているものと考えられる。そのため, $\mathrm{WO}_{3}-\mathrm{T}_{1} \mathrm{O}_{2}$ 薄膜は, $\mathrm{L}_{1}$ の蓄積が抑制され, $\mathrm{WO}_{3}$ 薄膜に比べ, 寿命が長くなっ たものと考えられる。

(1990-10-8 受理)

\section{文献}

1) B. W Faughnan, R S. Crandall and P M Heyman, RCA. Rev., 36, 177 (1975)

2) S. K Mahapatra , J Electrochem. Soc, 125, 284 (1978)
3）森田 廣, 䵫田浩志 ; 応用物理, 51, 488 (1982）

4) P Schlotter and L Pickelmann ; J Electron Mater., 11, 207 (1982)

5 ) 吉池信幸, 近藤繁雄, DENKI KAGAKU, 54, 423 (1986)

6) S. Hashımoto, H. Matsuoka, H Kagechika, M Susa and K. S. Goto ; J. Electrochem. Soc., 137, 1300 (1990)

7) S. Hashımoto and H Matsuka , J Electrochem Soc., (1991) (to be published)

8 ) S. Hashımoto and H. Matsuoka , J Appl Phys , (1991) (in press)

9）仁田 勇; X線結晶学（丸善, 1961)

10) R. J. Colton, A. L Guzman and J W. Rabalais , Accounts of Chemucal Research, 11, 170 (1978)

11) C D Wagner, W M Riggs, L E Davis, J F Moulder and G E Mullenberg ; Handbook of X-ray Photoelectron Spectroscopy, p 68 (Perkın-Elmer Corporation, 1979)

12) F S. Galasso , Structure and Properties of Inorganic Solıds (Pergamon Press, 1970)

13) H R. Zeller and H U Beyeler ; Appl. Phys., 13, 231 (1977)

14) J. V Gabrusenoks, P D Clkmach, A R Lusıs, J. J Kleperis and G M Ramans, Solvd State Ionıcs, 14, 25 (1984) 